\title{
Etnomusikologian yliopisto-opetus demokraattisen yhteiselämän kehitysalustana
}

Elämme keskellä sosiaalista murrosta, jonka kehitykseen vaikuttavat koronaviruspandemian eriarvoistavat seuraukset ja akuutti tarve parantaa oikeudenmukaisuutta polarisoituvassa maailmassa. Koronaviruspandemia on haurastuttanut sosiaalista kanssakäymistä. Samalla myös yhteiskunnallinen eriarvoistuminen jatkuu; jo viime vuosikymmeneltä saakka muun muassa Occupy Wall Street -liikkeen, Arabikevään, Hongkongin protestien sekä \#metoo- ja Black Lives Matter -liikkeiden esiin nostamat ongelmat ovat paljastaneet demokratian laajamittaista murentumista. Tämä herättää kysymyksiä siitä, miten kasvavat jännitteet ihmisten välillä ja fyysisen etäisyyden aika vaikuttavat jatkossa demokraattiseen yhteiselämään.

Näiden vaikeiden kysymyksien keskellä yliopistoilla on tärkeä vastuu: niiden tulee osallistua yhteisten ongelmien ratkaisemiseen ja opettaa opiskelijoille yhteiskunnan rakentamiseen tarvittavia tietoja ja taitoja. Yliopistolain $(2 \S)$ mukaan

[y]liopistojen tehtävänä on edistää vapaata tutkimusta sekä tieteellistä ja taiteellista sivistystä, antaa tutkimukseen perustuvaa ylintä opetusta sekä kasvattaa opiskelijoita palvelemaan isänmaata ja ihmiskuntaa. Tehtäviään hoitaessaan yliopistojen tulee tarjota mahdollisuuksia jatkuvaan oppimiseen, toimia vuorovaikutuksessa muun yhteiskunnan kanssa sekä edistää tutkimustulosten ja taiteellisen toiminnan yhteiskunnallista vaikuttavuutta.

Tässä epävakauden ja hyvinvoinnin tienhaarassa etnomusikologialla on mahdollisuus vaikuttaa tulevaisuuteen yliopistollisen tieteenalan ja oppiaineen ominaisuudessa. Nyt tarvitaan työtä avarakuuloisuuden edistämiseksi, ja siihen työhön etnomusikologit ovat hyvin varustautuneita. Etnomusikologit ovat jo pitkään tuottaneet tietoa, joka auttaa rakentamaan yhteisymmärrystä erilaisten ihmisten välille. Samanaikaisesti pyrkimys transformatiivisiin perspektiiveihin on muodostunut tärkeäksi osaksi suomalaisen etnomusikologian historiaa. Tämän osoittaa jo Suomen 
etnomusikologisen seuran alkuvuosina vallinnut puhetapa, jota Helmi Järviluoma kutsuu demokraattisen ja aktivoivan musiikkipolitiikan diskurssiksi (2005: 63). Sitä heijastivat seuran varhaiset musiikkipolitiikan keinot, joihin lukeutui muun muassa yhteistyö kansalaisjärjestöjen kanssa, kannanotto YLE:n musiikkipolitiikkaan ja paikallisten musiikkikulttuurien tutkimusprojektit (ks. Järviluoma 2005: 62). Vuosien saatossa yhteiskunnallisesta orientaatiosta on tullut oleellinen osa suomalaista etnomusikologiaa (Moisala 1994: 417). Yhteiskunnallisen orientaation muodostumiseen on vaikuttanut muun muassa kantaaottava ja kansallisidentiteettiä tukeva kansanmusiikintutkimus, vastavuoroisuutta painottava musiikintutkimus ja kulttuurivaihto sekä osallistavien toimintatutkimusmenetelmien käyttö musiikillisissa konteksteissa (ks. Donner 1984: 3; Piekkari 2002; Kurkela 2005: 53-58; Järviluoma \& Leppänen 2004; Järviluoma \& Leppänen 2012). Näistä lähtökohdista nousevana alana etnomusikologialla on paljon annettavaa suomalaiselle yliopistomaailmalle ja yhteiskunnalle.

Viime vuosien maailmanlaajuisten muutoksien myötä musiikintutkijoiden keskuudessa on noussut uudenlaisia keskusteluja tasa-arvoon liittyvistä aiheista (ks. Mononen \& Välimäki 2018; Seye \& Tiainen 2021; Ramstedt 2020; Åberg 2020). Nämä ajankohtaiset keskustelut kytkeytyvät kansainvälisesti huomioituihin eriarvoisuuden ongelmiin ja etnomusikologian uudistumistarpeisiin (ks. esim. Diamond \& Castelo-Branco 2021a, 2021b; Brown 2020; Pettan \& Titon 2015; Harrison ym. 2010; Araujo 2009; Averill 2003: 51). Seuratessani nykyhetken keskusteluja olen havainnut, että vielä toistaiseksi alan opetuksen sisältöjen ja menetelmien uudistamista on käsitelty suomalaisessa kirjallisuudessa niukasti. Artikkelini yleisenä tavoitteena onkin avata uutta keskustelua etnomusikologian opetuksesta ja sen yhteiskunnallisesta vaikuttavuudesta. Käytän etnomusikologiaa esimerkkialana osallistavan opetuksen hyödyllisyydestä. Huomioin aktivistisen musiikkikasvatuksen tutkimus- ja opetuskäytäntönä, joka voi yhtäältä ottaa kantaa ja vaikuttaa yhteiskunnallisen oikeudenmukaisuuteen sekä toisaalta herättää tietoisuutta ja keskustelua edesauttamalla ideologioiden ja valtarakenteiden kriittistä tarkastelua (Hess 2019). Huomioin myös kansainvälisen kirjallisuuden esille tuoman tarpeen kolonialismin kauaskantoisten vaikutuksien tunnistamiseen ja analysointiin musiikkitieteellisessä opetuksessa (Figueroa 2020; Thielsch 2020). Tässä artikkelissa tarkoitukseni on erityisesti osoittaa, millä tavoin etnomusikologian yliopisto-opetus voi edesauttaa dialogiseen keskusteluun tarvittavien kykyjen kehittämistä ja siten harjaannuttaa opiskelijoita demokraattiseen yhteiselämään.

Aineistona käytän omakohtaisia kokemuksiani; näytän, miten kokemukseni etnomusikologian opiskelijana ovat kehittäneet pedagogista ajatteluani ja opetustyöni tavoitteita. Ensin kuvailen kokemuksiani jatko-opiskelijana Pennsylvanian yliopistolla Yhdysvalloissa. Sitten kerron, kuinka dialogin kykyjen harjoituttaminen toteutuu 
opetustyössäni Helsingin yliopistolla. Esimerkkini sijoittuvat etnomusikologian opintojen kahdelle keskeiselle kurssille: kenttätyökurssille ja Johdanto maailman musiikkikulttuureihin -kurssille.

Käsittelen oppimis- ja opetuskokemuksiani tarkastelumallilla, jota voisi kutsua "yliopistojenväliseksi" lähestymistavaksi. Kahdelle mantereelle sijoittuvien erilaisten kurssikokemuksieni käsitteleminen jatkumona saattaa herättää epäilyjä niiden sopivuudesta yhdistettyyn tarkasteluun. Olen kuitenkin vakuuttunut siitä, että malli mahdollistaa uudenlaisen hedelmällisen analyysin. Sovellan Heikki Mikkelin ja Jussi Pakkasvirran (2007: 65) kuvaamaa tieteidenvälisyyttä: "Kyseessä on tutkimusprosessi, jossa hyödynnetään paitsi eri tieteiden tietoa myös usean tieteenalan käsitteitä, näkökulmia, teorioita ja menetelmiä ja jossa ainekset myös osaksi sulautuvat yhteen". Käsillä olevassa tapauksessa etnomusikologian tieteenalan konteksti on vakio, mutta lähestymistapaani voi luonnehtia jokseenkin samantapaiseksi kuin Helmi Järviluoman (2008) kuvaamaa opinalojen rajoja käytännössä ylittävää tutkimustyötä. Hänen mukaansa tieteiden välisyys konkreettisena siirtymisenä, eli tutkijan liikkuminen instituution tai opinalan piiristä toiseen, voi uudistaa tieteenalaa ja edesauttaa elämään kriittisemmin ja tietoisempana toiminnan rajoitteista ja mahdollisuuksista. Rinnakkainen asetelmani toimii etnomusikologiaa ohjaavan relativismin periaatetta noudattaen: opetukseen ja oppimiseen liittyvää toimintaa tarkastellaan molemmissa konteksteissa niissä vallitsevien ehtojen mukaisesti. Samalla toivon, että esimerkkini auttavat tuomaan uusia ideoita ja toimintatapoja oppimisympäristöön suomalaisessa yliopistomaailmassa.

Jäljittäessäni ja tarkastellessani opettajaminääni käytän pääasiassa itsereflektiota. Reflektiivisyyteni seuraa nykyään vakiintuneita etnomusikologisia käsityksiä tiedontuotannon epistemologisista tekijöistä ja niiden näkyväksi tekemisen tarpeesta. Reflektio on erityisesti kenttätyökirjallisuudessa laajalti käytetty tarkastelutapa, joka nostaa etualalle ihmissuhteiden merkityksen tiedontuotannossa (ks. Barz \& Cooley 2008; Gould \& Uusihakala 2016; Rannikko \& Rannikko 2021). Gould (2016: 11) kiteyttää reflektion tavoitteeksi tuottaa kysymyksiä siitä, miten data syntyy ja mikä on tutkijaminän osa tässä prosessissa. Artikkelissani ohjaan huomiota näiden kysymyksien soveltuvuuteen myös opetustyön tarkastelussa. Toisin sanoen tuon tarkastelussani näkyväksi, miten oppiminen syntyy ja mikä on opettajaminäni osa tässä prosessissa.

Kurssitapahtumien analyysissa sovellan yhteiskuntafilosofi Kai Alhasen näkemyksiä kyvyistä, joita tarvitaan demokratiaa edistävässä dialogissa. Alhasen (2016: 13) mukaan dialogi on tietynlaista "keskustelua, jossa ihmiset tutkivat, millaisia merkityksiä he antavat yhdessä käsiteltäville asioille”. Tämä on tärkeää, koska dialogin kautta osapuolet voivat alkaa ymmärtää toistensa kokemuksia ja niiden heille tuottamia 
merkityksiä. Tämän kaltainen tiedon jakaminen dialogisessa keskustelussa rakentaa luottamusta ja ymmärrystä osallistujien kesken. Osallistuminen dialogiseen keskusteluun vaatii kuitenkin kykyjä, joita on harjoiteltava. Alhasen mukaan näihin kykyihin kuuluvat virittäytyminen, kuvittelu, harkinta, leikki ja usko. (Alhanen 2016: 19.) Nämä kyvyt kytkeytyvät olennaisesti etnomusikologien työskentelyyn sekä kuuntelijoina että keskustelukumppaneina erilaisissa musiikillisissa yhteisöissä. Etnomusikologian kursseilla dialogin kykyjä harvoin harjoitellaan tarkoituksellisesti, mutta ne ovat implisiittinen osa oppimisprosessia. Siksi niiden havainnoiminen auttaa tarkentamaan ymmärrystä siitä, miten oppiminen syntyy etnomusikologian yliopisto-opetuksessa.

Transformatiivisen eli uudistavan oppimisen teoreettinen lähestymistapa määrittää näkemystäni oppimisesta. Transformatiivisen oppimisen lähtökohtana on konstruktivistinen käsitys yksilön henkisen kasvun prosessista. Kuten Nevgi ja Lindblom-Ylänne kirjoittavat:

Transformatiivisen oppimisteorian mukaan oppiminen ei ole mallien toistamista sellaisenaan vaan oppiminen on asioiden pohtimista, reflektointia ja kriittistä kyseenalaistamista (Mezirow et al 1996; 1997). Teorian mukaan ihmisen ajattelua sitoo ja ohjaa hänen oman kulttuuritaustansa ja aikaisempien kokemustensa muodostama viitekehys. Oppiminen on kokemusten tulkintaa ja uusien merkityksien luomista. Ihmisen on tultava tietoiseksi siitä, millä tavoin ja mistä lähtökohdista käsin hän tulkitsee kokemuksiaan. Ilman tietoista pohdintaa hänen oppimisensa ei tue hänen kehittymistään ja kasvuaan ihmisenä. (Nevgi \& Lindblom-Ylänne 2009: 209.)

Etnomusikologian opiskelu tarjoaa hedelmälliset lähtökohdat transformatiiviselle oppimiselle, koska jo peruskursseilla opiskelijat johdatetaan pohtimaan musiikkia kulttuurisidonnaisena tapahtumana relativismin periaatteen avulla. Relativismi on yksi etnomusikologian perustavista käsitteistä, joten sen opettaminen läpäisee kaikki oppimisen alueet, oli kyseessä mikä tahansa musiikkikulttuuri. Esimerkiksi maailmanmusiikin kursseilla paljon käytetyssä kirjassa Excursions in World Music Timothy Rommen (2016: 10) seuraa Bruno Nettlin ajatusta siitä, että kaikkia musiikkikulttuureja tulee tutkia konteksteissaan niiden omilla ehdoilla. Rommen myös painottaa, kuinka tärkeää on tiedostaa musiikkien maailmanlaajuinen erilaisuus, jotta tieto niiden erilaisuudesta voi johtaa uusiin oivalluksiin ja rikkaisiin ja merkityksellisiin musiikillisiin kohtaamisiin, jotka kuvaavat samankaltaisuutta, solidaarisuutta ja yhteisiä näköaloja (Rommen 2016: 4-5). Hänen mukaansa "avarakuuloinen lähestymistapa samankaltaisuuteen ja erilaisuuteen - sen tunnustaminen, että käsitteet, kuten koti ja vieras, itse ja muut, rakennetaan ja muuttuvat jatkuvasti näkökulman perusteella 
- on ratkaisevan tärkeää" tarkasteltaessa maailman musiikkikulttuureja (Rommen 2016: 6). Oivaltamista, uusien merkityksien oppimista ja avarakuuloisuutta lisäävien tietojen ja taitojen kartuttaminen sekä niiden vaikutukset oppijaan ovat siten transformatiivista oppimista.

\section{Dialogin kykyjen harjoittelu etnomusikologian kenttätyön kurssilla}

Relativismin periaatteisiin sitoutuneet, yliopistolta ulospäin suuntautuvat ja paikallisyhteistyönä toteutetut etnomusikologian kurssit tarjoavat opiskelijoille hyvän tilaisuuden transformatiiviseen oppimiseen. Varsinkin soveltavan etnomusikologian kirjallisuus antaa esimerkkejä yliopistokursseista, joilla opiskelijat ovat päässeet osallistumaan paikallisyhteisön musiikilliseen toimintaan ja jotka ovat vaikuttaneet opiskelijoiden ymmärtämyksen kasvamiseen sekä suhteiden kehittymiseen osallistujien välillä (Usner 2010; Averill 2003). Esimerkiksi palveluoppimisena ${ }^{1}$ toteutetuilla kursseilla opiskelijat ovat työskennellet dementiapotilaiden kanssa iäkkäiden yhteisöissä, taideorganisaatioissa ja peruskouluissa. Näissä hankkeissa opiskelijat ovat saaneet spesifejä tietoja ja taitoja. Heidän sosiaalinen tietoisuutensa on laajentunut ja avoimuutensa erilaisuudelle sekä yhteisöön kuulumisen tunteensa on kasvanut. Joillain opiskelijoilla on myös herännyt halu osallistua aktivismiin, toiset ovat saaneet uusia näkökulmia ja arvioineet arvojaan uudelleen. Jotkut ovat saaneet kontakteja ja ideoita ammatilliseen suuntautumiseen. Hankkeet ovat myös tuottaneet nautintoa ja tyytyväisyyttä sekä halua vaikuttaa positiiviseen muutokseen maailmassa (Muller \& Öhman 2021; Gubner 2018; Summit 2015; Usner 2010; Alviso 2010; Averill 2010, 2003). Toisaalta kokemukset palveluoppimisesta ovat myös auttaneet opettajia käsittelemään omaan tutkimukseensa liittyviä kysymyksiä (Summit 2015: 219). Lähempi katsaus näihin vaikutuksiin paljastaa, että monet positiiviset tulokset liittyvät sosiaalisiin suhteisiin, joita osallistujat luovat palveluoppimisen aikana sekä niiden reflektoimiseen jälkeenpäin. Yllä kuvatut oppimiskokemukset heijastavat siten transformatiivisen oppimisen teorian keskeisiä osia.

Kenttätyön vuorovaikutuksellisen luonteen huomioiden etnomusikologisen kenttätyön opetus tarjoaa tilaisuuden dialogisen keskustelun harjoitteluun. Dialogisen keskustelun mahdollistaa lähestymistapa, jonka mukaan tutkija ei ole kentällä mekaanisesti kerätäkseen aineistoja, vaan hänellä on halu oppia ymmärtämään, mitä

1 Tässä alun perin yhdysvaltalaisessa, filosofi John Deweyn ideoihin perustuvassa pedagogisessa toimintamallissa ("service learning") yhdistyy teoreettinen ja käytännöllinen koulutus. Palveluoppiminen on saanut jalansijaa myös eurooppalaisissa yliopistoissa (Furco \& Norvell 2019). 
musiikilliseen toimintaan osallistuvat ihmiset itse ajattelevat musiikistaan ja mitä merkityksiä he sille antavat (Titon 2008: 25). Koska kenttätyö on etnomusikologisen tiedontuotannon ydinaluetta (Moisala \& Seye 2013: 6; Rice 2008: 46), on kenttätyötaitojen opiskelu hyvin tärkeää. Samalla opiskelu on koulutusta erilaisten yksilöiden kohtaamiseen: "kenttä" on ensisijaisesti niitä suhteita, jotka yksilö rakentaa ja ylläpitää ihmisten kanssa (Titon 2008: 32-33). Pyrkimys neutraaliuuteen voi olla hyvä periaate, mutta haastattelu on aina vuorovaikutustilanne, jossa toinen osapuoli ei voi yksin päättää, jääkö hän kuuntelijaksi (Ruusuvuori \& Tiittula 2017: 81). Lisäksi se miten hyvin yksilö pärjää kentällä, riippuu siitä, miten hän kykenee siellä sopeutumaan. Käytännössä "sopeutuminen" käsittää tutkijan kyvyn vastata ennakoimattomiin tilanteisiin spontaaneilla reaktioilla ja ratkaisuilla, jotka ylläpitävät ja edistävät tutkimuksen tavoitteita (Campbell \& Lassiter 2014). Nämä tilanteet linkittyvät oleellisesti inhimillisiin suhteisiin, jotka rakentuvat erilaisissa kohtaamisissa kenttätyön aikana. Lyhyesti sanottuna tutkijan on kyettävä olemaan hyvä kuuntelija ja keskustelukumppani.

Etnomusikologian kenttätyökurssi antoi minulle mahdollisuuden oppia arvostamaan dialogin kykyjä ja niiden merkitystä yhteistoiminnan onnistumiselle. Kurssin aikana en opiskellut niitä tietoisesti, mutta reflektion ja Alhasen teorian avulla kykenen jälkeenpäin havainnoimaan, kuinka opettava dialoginen vuorovaikutus syntyi hetkellisten keskusteluiden sekä muun yhteistoiminnan aikana. Seuraavaksi kuvaan, kuinka harjoittelin Alhasen teorian mukaisia dialogin taitoja, joihin kuuluvat virittäytyminen, kuvittelu, harkinta, leikki ja usko (Alhanen 2016: 19). Sen jälkeen kerron, kuinka tämä transformatiivinen oppimiskokemus johti oman pedagogisen ajatteluni kehittymiseen ja toteuttamiseen yliopisto-opetuksessa.

Vuonna 2008 osallistuin jatko-opiskelijana Pennsylvanian yliopistossa Philadelphiassa etnomusikologisen kenttätyön kurssille. Kurssi järjestettiin osana yhteistyöhanketta, jossa osapuolina olivat Pennsylvanian yliopiston musiikinosasto ja Quba Institute for Arabic and Islamic Studies (jäljempänä Quba-instituutti tai Quba). Quba-instituutti on muslimiyhteisö ja islamin näkökulmaan pohjautuva peruskoulu. Projektiryhmääni kuului lisäkseni neljä teini-ikäistä oppilasta Quba-instituutista ja Pennsylvanian yliopiston (Penn) perustutkinto-opiskelija. ${ }^{2}$ Valmistimme multimediaprojektin hiphop-kulttuurin merkityksistä Quba-instituutin jäsenien keskuudessa.

Tämä yhteistyöhanke toteutettiin yliopiston yhteiskunnallisen toiminnan keskuksen (Netter Center for Community Partnerships) koordinoimana palveluoppimiskurssina

\footnotetext{
2 Käytän artikkelissa sanaa "oppilas" peruskouluikäisistä Quba-instituutin oppilaista ja sanaa "opiskelija" puhuttaessa aikuisista yliopisto-opiskelijoista.
} 
(Academically Based Community Service course, "ABCS"). ABCS-kurssit tarjoavat perinteistä tutkija-tutkittava-asetelmaa demokraattisemman mallin tiedon tuottamiselle ja oppimiselle. Ne ovat tärkeä osa yliopiston ja paikallisyhteisöjen välistä yhteistyötä, jonka kautta yliopisto pyrkii toimimaan yhteiskunnallisesti vastuullisena ja laajempaan sosiaaliseen ympäristöönsä rakentavasti vaikuttavana instituutiona. ABCS-kursseilla on myös tärkeä rooli yliopiston kansalaiskasvatuksellisen tehtävän toteuttamisessa. Kenttämenetelmien kurssi oli jatkoa etnomusikologian professori Carol A. Mullerin vuonna 2001 aloittamalle ABCS-kenttätyökurssien sarjalle nimeltä "West Philly Music Project". Vuosien mittaan Mullerin johtamat erilaiset ABCS-kenttätyökurssien toteutukset ovat käsittäneet hankkeita Philadelphian gospel-musiikkikulttuurista ja gospel-musiikin esityshistoriasta, jazz-musiikin muistitietohistoriasta sekä kulttuuriseen ilmaisuun liittyvistä teemoista eri muslimiyhteisöjen keskuudessa. Vaikka Philadelphiassa on erityisen rikas ja monipuolinen musiikkielämä, monista paikallisista musiikkikulttuureista ei ole arkistoitua tietoa. Siksi keskeisenä tavoitteena kaikissa yhteistyöprojekteissa, kuten Quba-instituutin projektissa, on ollut paikallishistoriallisen arkiston luominen dokumentoimalla äänellistä ja musiikillista aineistoa.

Yliopisto-opiskelijoille kurssi opetti ensisijaisesti kenttätyötaitoja. Kurssi kesti koko kevätlukukauden, tammikuulta toukokuulle. Alkuun me opiskelijat tapasimme yliopistolla viikoittaisissa seminaareissa, joissa käsiteltiin kenttätyöhön ja islamin tutkimukseen liittyviä aiheita. Helmikuussa seminaarien ohessa aloitimme yhteistyön Quban oppilaiden kanssa. Siihen kuuluivat viikoittaiset tiimitapaamiset, joissa keskustelimme tausta-aineistoista, kuten laulunsanoista ja hiphop-aiheisista radioohjelmista, joita jokainen oli kuunnellut omalla ajallaan. Niiden pohjalta pohdimme aiheita etnografiselle tutkimukselle. Etnografisessa tutkimuksessa otimme valokuvia ja teimme haastatteluja, joita taltioimme nauhoitteille ja videolle. Samoin keinoin taltioimme myös kontekstuaalista materiaalia. Hankkeen lopussa tiimi kokoontui yliopistolle editoimaan ja valmistelemaan lopullisen etnografisen filmin. Se näytettiin yliopistolla pidetyssä hankkeen päätösjuhlassa, johon osallistui oppilaiden ja Quba-instituutin johtajien lisäksi oppilaiden vanhempia, sukulaisia ja ystäviä.

Tarkastelu hiphop-kulttuurin merkityksistä Quba-instituutin jäsenien keskuudessa tarjosi ABCS-kenttätyökurssien sarjaan erityisesti nuoria kiinnostavan kohteen ja musiikillisesti sopivan aiheen, koska Quba-instituutissa afrikkalaisamerikkalaisia musiikkityylejä, kuten jazz ja hiphop, pidetään yleisesti tärkeänä osana yhteisön kulttuuriperintöä (Öhman 2020). Vaikka projekti opetti Quban oppilaille musiikintutkimuksen perusteita, yhteistyön toisena merkittävänä tausta-ajatuksena toimi vastavuoroisuus, jonka toteutumiseksi yliopisto-opiskelijoilla oli tehtävänä mentoroida Quban oppilaita college-opiskelua varten. Esimerkiksi projektin vanhimpana jäsenenä jaoin tiimitapaamisissamme vaihtuvat roolit: jokainen projektin jäsen toimi 
vuorollaan keskustelun vetäjänä, kirjurina ja ajanpitäjänä. Tämä opetti taitoja ryhmätyöskentelyyn, joka on tärkeä osa opiskelua yliopistossa.

\section{Dialogin kyky 1: Virittäytyminen}

Sain kokemusta demokratiaa rakentavien dialogisten kykyjen oppimisesta jo kenttätyökurssin alkumetreillä. Tästä esimerkkinä mainittakoon virittäytymisen kyky, jota harjoittelimme ensimmäisessä tiimitapaamisessa jo ennen varsinaisen musiikillisen keskustelun käynnistymistä. Alhasen (2016: 124-139) mukaan keskustelijat dialogissa pyrkivät virittäytymällä eläytymään toistensa kokemuksiin. Virittäytyneisyyden luomiseen tarvitaan yksilön herkistymistä vastaanottamaan aistimuksia ja niiden vaikutusta itsessä sekä vuorovaikutuksellista läsnäoloa, joka muokkautuu omien ja muiden kokemuksien yhteisvaikutuksesta. Samalla keskustelijat käyttävät ilmeitä, eleitä ja ääntä virittäytyessään kohti toisia ja heidän kokemuksiaan (2016: 134). Tiimitapaamisemme aloitus viivästyi, koska Quba-instituutin oppilaan täytyi lähteä hakemaan korjausapua printterille, jolla oli tarkoitus tulostaa laulunsanoja keskustelumme pohjaksi. Aikamme kuluksi aloimme puhua urheilusta. Keskustellessamme yksi oppilas kertoi tavoitteestaan päästä pelaamaan amerikkalaista jalkapalloa yliopistojoukkueessa. Toinen oppilas vastasi siihen kertomalla seuraavansa enemmän eurooppalaista jalkapalloa, joka ei ole Philadelphiassa yhtä suosittua kuin amerikkalainen jalkapallo, mutta hänen perheessään siitä pidetään, koska perhe on asunut Saudi-Arabiassa, jossa se on suosittu urheilulaji. Vastavuoroisesti minun oli helppo eläytyä kokemukseen eurooppalaisen jalkapallon suosiosta, koska eurooppalainen jalkapallo on myös suosittua kotimaassani Suomessa. Ilahtunut eläytyminen näkyi varmasti ilmeistäni ja eleistäni. Osallistuin keskusteluun kertomalla pelanneeni Suomessa koripalloa ja saaneeni siksi mahdollisuuden lähteäYhdysvaltoihin, kun pääsin pelaajaksi Marylandin yliopiston naisten koripallojoukkueeseen. Hyväntuulisen keskustelun edetessä vuorovaikutuksellinen läsnäolomme vahvistui, kun opimme toistemme erilaisista urheilulle antamista merkityksistä. Vaikka taustamme olivat hyvin erilaiset, huomasimme merkityksissä mielenkiintoisia yhtäläisyyksiä, jotka auttoivat eläytymään toistemme kokemuksiin ja siten kasvattamaan keskinäistä ymmärtämystä ja luottamusta. Toteuttamassamme etnografisessa videossa kiinnostus urheilua kohtaan tuli esille haastatteluissa sekä kuvasarjana välitunnilla pelatusta amerikkalaisesta jalkapallosta.

\section{Dialogin kyky 2: Kuvittelu}

Tiimitapaamisen keskustelun edetessä pääsimme nopeasti myös harjoittelemaan kuvittelukykyä, joka on yksi demokratian rakentamiselle oleellisista dialogisista kyvyistä. 
Kuvittelukyvyn monipuolinen opetteleminen ja soveltaminen aineistontuottamisessa jatkui koko hankkeen ajan. Sen lisäksi, että virittäytyminen auttaa luomaan dialogin edellyttämää empatiaa ja luottamusta, kuvittelukyky on Alhasen (2016: 140-156) mukaan mielikuvituksen elävöittämää luovaa ajattelua, jonka kautta yksilö pystyy syvällisesti käsittelemään toisten ihmisten erilaisia kokemuksia. Siten ihminen myös kykenee aidosti laajentamaan omaa ymmärtämystään maailmasta. Tämä on erityisen tärkeää taustoiltaan hyvin erilaisten ihmisten kohdatessa. Alhanen (2016: 150-151) syventää tätä näkemystä toteamalla, että: "toisten ihmisten vierauden hyväksyminen, siihen tutustuminen ja sen eläytyvä ymmärtäminen onnistuu vain avaamalla ja venyttämällä oman kokemuksen rajoja kuvittelukyvyn avulla”.

Kuvittelukyvyn keskeisenä voimanlähteenä toimii mielikuvitus. Jo aiemmin mainitsemassani keskustelussa opimme tuntemaan toisiamme ja pystyimme kuvittelemaan toistemme elämänvaiheita urheilun kautta. Quba-instituutin oppilaan kertoessa kokemuksestaan Saudi-Arabiassa me muut saatoimme yrittää kuvitella hänen kuvaamaansa jalkapallokulttuuria. Kertoessani omista kokemuksistani urheilun parissa muut puolestaan saattoivat kuvitella, minkälaista suomalainen koripallokulttuuri voisi olla. Meillä ryhmän jäsenillä oli erilaiset taustat erityisesti uskonnon, etnisyyden ja kansalaisuuden suhteen, mutta tämän kaltaisten monipuolisten keskustelujen avulla pääsimme tutustumaan toistemme kokemusmaailmoihin.

Käytännössä kuvittelukyky oli arvokas työväline. Suunnitellessamme aineiston keräämiseen liittyviä aktiviteetteja kuvittelimme vaihtoehtoja tutkimuksen aiheelle ja mietimme, kuka haluaisi tulla haastateltavaksi. Suunnittelun jälkeenkin kuvittelun tärkeys näkyy kerättyjen aineistojen monipuolisuudessa. Haastattelujen aikana usein spontaanisti edenneet keskustelut ja videolle taltioituneet tilannekuvat yhteisön tapahtumista osoittavat projektin luovan toteutuksen tieteen ja taiteen risteyksessä. Aineisto antoi esimerkin siitä, miten "kuvittelukyky mahdollistaa myös taiteen keinoin syntyvien toisenlaisten havaitsemistapojen ja rinnakkaistodellisuuksien luomisen ja niiden eläytyvän käsittelemisen" (Alhanen 2016: 146). Valmis kollaasityyliin toteutettu multimediaprojektimme välittää rikkaan kuvan Quba-instituutin yhteisön suhteesta hiphop-musiikkiin, joka sekä perustuu uskonnolliseen maailmankuvaan että ammentaa vaikutteita amerikkalaisesta populaarikulttuurista.

\section{Dialogin kyky 3: Harkinta}

Kuten kuvittelun kykyyn, myös harkinnan kykyyn liittyy valintojen tekemistä. Harkinta eroaa kuitenkin kuvittelusta, koska se käsittää lähemmin valintojen todelliset seuraamukset. Alhanen (2016: 157) painottaa harkinnan loogisuuden periaatteita toteamalla, että dialogissa harkinta käsittää "faktoihin nojaavaa analyyttisyyttä ja 
johdonmukaisuutta”. Kenttätyön aikana tutkija kohtaa monia yllättäviä tilanteita, joissa hän joutuu harkitsemaan reaktiotaan ja sanavalintojaan. Näitä saattavat olla monet suhteiden rakentamiseen ja ylläpitämiseen liittyvät vuorovaikutustilanteet sekä haastattelut. Yhteistyömme aikana harkintaa vaativia tilanteita tuli monia, mutta samalla koin, että aikuisena ja yliopistoa edustavana jatko-opiskelijana minun tuli harkita valintojani erityisen tarkasti.

Tästä esimerkkinä voi jälleen antaa ensimmäisessä tapaamisessa tilanteen, jolloin oppilas palasi tulostettujen laulunsanojen kanssa keskusteluun. Ennen papereiden jakamista hän varoitti osallistujia siitä, että joissain niistä oli negatiivisia sanoja, mutta hän kuitenkin näki niiden käsittelemisen tarpeellisena. Muistan keskustelun hyvin, koska siinä hetkessä tiedostin asemani aikuisena ja yliopistoa edustavana jatko-opiskelijana. Siihen saakka olin tietoisesti välttänyt aiheita, jotka saatettaisiin nähdä epäsopivina yläasteikäisille, kuten hiphop-kappaleet, joissa puhutaan alkoholin juomisesta tai joissa kiroillaan. Lisäksi kulttuurin ulkopuolisena en nähnyt sopivaksi sitä, että vahvasti kritisoisin hiphop-musiikkia, jonka opiskelijat kokivat omaksi kulttuurikseen.

Koska oppilaat halusivat käsitellä haastavia teemoja, päätin liittyä keskusteluun, jossa kuitenkin tarkasti harkitsin sanojani ja eleitäni. Vaihtoehtoisesti olisin voinut olla hiljaa tai yrittää johdattaa keskustelua "turvallisempiin" aiheisiin. Valinnassani luotin kuitenkin myös siihen, että Quba-instituutin opettaja, joka toisinaan tuli mukaan keskustelemaan ja sattui silloin olemaan läsnä, muistuttaisi oppilaita, jos keskustelun sisältö ei vastaisi koulun linjauksia. Tässä tilanteessa jouduin harjoittelemaan dialogikykyihin kuuluvista taidoista harkintaa, eli sitä, että "henkilö punnitsee ennen kuin toimii, mitä keinoja hänen on käytettävä päämääriensä saavuttamiseksi ja mitkä hänen kaavailemistaan teoista tuottavat millaisiakin seurauksia" (Alhanen 2016: 161).

Dialogisissa keskusteluissamme pystyimme yksilöinä samanaikaisesti sekä kehittämään omaa harkintakykyämme että suuntaamaan sitä yhdessä ratkaistaviin ongelmiin (Alhanen 2016: 159). Laulunsanojen analysoinnista kehittyi yhteisöllisen harkinnan prosessi, jossa osallistujat yhdessä miettivät kausaalisuhteita ja harkitsivat eri näkökulmia oman harkintansa parantamiseksi (Alhanen 2016: 169). Keskustelussa Quban oppilaat vertasivat "positiivisia lauluja" kuten muslimi-rap-artisti Lupe Fiascon kappaletta Hurt Me Soul ja "negatiivisia lauluja", joiden sanoituksissa puhutaan esimerkiksi väkivallasta. Keskustelussamme muutama Quban oppilas nosti esille sen, että "negatiivinenkin" laulu saattaa kiehtoa kuulijaa, koska siinä on hyvä "soundi". Samalla yhdessä päättelimme, että levy-yhtiöillä ja medialla on tärkeä rooli siinä, miten kuluttajien kiinnostusta herätetään shokeeraavilla sanoituksilla ja heitä houkutellaan kuuntelemaan mukaansatempaavilla "soundeilla". 


\section{Dialogin kyky 4: Leikki}

Yhteistyömme prosesseissa opin erityisen paljon leikin kyvyn voimasta Qubainstituutin oppilailta. He auttoivat minua irtaantumaan kankeasta tutkija-tutkittava-kaavasta, ja heidän luova näkemyksensä projektin toteuttamiseen johti minut kyseenalaistamaan perinteisen tieteellisen tiedon ja tietämisen oletettuja rajoja. Usein oppimiseni tapahtui juuri sellaisissa tilanteissa, joissa Alhasen sanoja mukaillen tutkimme leikin kyvyllä kuvitteellisten asiantilojen mahdollisuuksia ja kokeilimme luovasti erilaisia seurauksia sitoutumatta niihin konkreettisesti. Ne olivat tilanteita, joissa osallistujat leikittelevät omista tiedoistaan ja muististaan ammentamillaan aineksilla kukin lisäämällä ideoita tai jatkamalla toistensa ajatuksia. (Alhanen 2016: 173-187.) Tieteentekijöille leikki voikin tarjota oivan työkalun, mistä esimerkkinä Alhanen (2016: 183) antaa tieteellisen keskustelun, jossa osallistujat pallottelevat "lukuisilla erilaisilla tutkimusideoilla tai koeasetelmilla". Myös muunlaisissa keskusteluissa monimutkaisista asioista osallistujat voivat leikin kautta irrottautua kaavamaisista oletuksista, oppia uutta ja tuottaa uudenlaisia ideoita (Alhanen 2016: 185). Yhteistyömme aikana opin arvostamaan leikin rikastuttavaa vaikutusta musiikilliseen etnografiaan.

Projektissamme tämän kaltainen leikki tuli erityisen näkyväksi haastattelutilanteissa. Quba-instituutin oppilaat haastattelivat pääasiassa omia koulukavereitaan. Silloin he saattoivat heittäytyä iloiseen roolipeliin: haastattelija tekeytyi Music Televisionin reportteriksi, jonka kysymyksiin vastatessaan haastateltavat vastasivat hauskuttelevaan sävyyn, jota korostivat muiden mukana olleiden naurunpurskahdukset. Varsinkin "reportterin" kysymys "Kuka on lempiräppärisi?" antoi vastaajille mahdollisuuden poiketa haastattelutilanteen kaavamaisuudesta ja kehitellä sitä omilla ilmaisuilla. Kyselyn kiistaton voittaja oli muslimi-rap-artisti Lupe Fiasco, jonka nimen eräs haastateltava luovasti stilisoi värittäen ja venyttäen vokaaleja "Fias-co!" Toinen lisäsi nimen päätteeksi "It's good stuff!", johon hänen ystävänsä lisäsi kutsu ja vastaus tapaan "That's right brother!". Haastattelussa tapahtunut leikittely kehitti osallistujien haastattelutaitoja ja tuotti uusia näkemyksiä hiphop-musiikin merkityksistä itsensä ilmaisulle ja yhteisöllisyydelle Quba-instituutissa. Kuten olen toisaalla (Öhman 2020) kirjoittanut, nuorisolle suunnatusta mediasta poimittujen mallien vaikutuksesta haastattelut eivät muistuttaneet perinteistä etnografiaa, mutta ne tuottivat tieteellisesti tärkeitä kysymyksiä tiedontuotannon tavoitteista ja tarkoituksista.

\section{Dialogin kyky 5: Usko}

Yhteistyömme tarjosi lyhytaikaisen mutta samalla selkeän järjestelmällisen tilan demokratian rakentamiseen olennaisen uskon kyvyn harjoittelemiseen. Kuten Alhanen 
toteaa, monia hankalia yhteiskunnallisia asioita ratkottaessa dialogi on vaativa keskustelemisen tapa, jonka onnistumiseksi on tehtävä pitkäjänteisiä yhteisiä ponnistuksia. Osallistujien on kyettävä pitämään mielessään ne päämäärät ja ihanteet, joiden toteutumiseksi keskustelua käydään. Siihen tarvitaan "osallistujien uskoa keskinäisen ymmärryksen syntymiseen, luottamuksen muodostumiseen ja uusien, käyttökelpoisten ideoiden ilmaantumiseen" (Alhanen 2016: 191). Samalla on myös toimittava. Koska projektimme tehtiin palveluoppimisen kurssilla, se kesti vain yhden lukukauden verran ja testasi vain rajallisesti osallistujien uskoa yhteisiin päämääriin. Pintapuolisesti päämääränä voisi nähdä vain projektin toteuttamisen. Yhteiskunnallisesti arvokkaampi tavoite oli kuitenkin yliopisto-opiskelijoiden ja Quba-instituutin oppilaiden välisen yhteistoiminnan onnistuminen. Tämä edellytti osallistujilta sitoutuneisuutta ja tahtoa, jotka konkretisoituvat tekoina.

Usko yhteisten päämäärien saavuttamiseen kasvoi yhteistyön etenemisen myötä. Jo ensimmäisessä tapaamisessa sitä edesauttoivat pienet eleet, joita Alhanen (2016: 197) kutsuu dialogitilanteiden rituaaleiksi, kuten vuorovaikutteisten puhetapojen käyttö (esimerkiksi "tuosta, mitä sanoit, tulee mieleeni”) ja tuolien asettaminen rinkiin osallistujien tasa-arvoisuuden merkiksi. Myös käytännön tehtävissä osallistujien kesken vallitsi innokas ja määrätietoinen halu toteuttaa projektin suunnittelu ja haastattelut ajallaan. Omakohtaisesti jouduin harjoittelemaan uskon kykyä esimerkiksi silloin, kun etnografian tuottaminen alkoi poiketa itselleni turvallisesta ja tutusta tieteellisestä kaavasta. Toisaalta ryhmämme innostuneisuus vahvisti luottamustani tavoitteiden saavuttamiseen. Projektin valmistuessa yhteistä uskoa vahvisti ryhmän ulkopuolisten henkilöiden tuki. Tällaista tukea saimme Quban opiskelijoiden muusikkoystävältä, joka antoi musiikkinsa projektin käyttöön, sekä Quba-instituutin johtajalta Imam Anwar Muhaiminilta, joka luovutti arkistostaan tiimin käyttöön videotallenteita aiemmista Quban järjestämistä Jumah in the Park -tapahtumista, joissa pidettiin hiphop-konsertteja.

Laajemmin katsottuna tämä palveluoppimisena toteutettu projekti vaati osallistujilta uskoa myös demokraattisiin ihanteisiin, kuten oikeudenmukaisuuteen ja yhdenvertaisuuteen. Yhteistyössämme näiden ihanteiden toteutuminen ei ollut itsestäänselvyys, vaan osallistujien oli keskustelussa jatkuvasti työstettävä ja ylläpidettävä niitä. Esimerkiksi kaikessa vastavuoroisessa keskustelussa minun oli pidettävä mielessä, että minulla oli merkittävä valta-asema yliopisto-opiskelijana ja valkoisen ihonvärini ja kristillisen taustani mukaan valtavirtaa edustavana aikuisena. Kokonaisuudessaan tämä oppimiskokemukseni ohjasi painottamaan omassa pedagogisessa ajattelussani dialogin tärkeyttä. Seuraavaksi siirryn yliopisto-opettajan perspektiiviin ja otan lähempään tarkasteluun muutaman teeman, jotka ovat nousseet oleellisesti esille opetustyössäni etnomusikologian kursseilla. 


\section{Johdatus maailman musiikkikulttuureihin -kurssin opetus dialogin kykyjen harjoitusalustana}

Kansainvälistyminen on jo pidempään ollut yksi yliopistojen keskeisistä tavoitteista. Sen mukaan yliopistot pyrkivät tarjoamaan opiskelijoille kansainvälisiä kokemuksia ja valmiuksia työskentelemiseen globalisoituneessa maailmassa. Niihin kuuluvat myös taidot ja asenteet, joiden kautta opiskelijat oppivat käymään vuoropuhelua erilaisten keskustelijoiden kanssa. Valmiuksien opettamisessa opettajat ovat avainasemassa luennoitsijoina ja keskustelun vetäjinä (Smeds 2016). Heidän on siksi myös hallittava dialogin kykyjä. Tämä on myös ensiarvoisen tärkeää yliopistojen yhä enemmän suuntautuessa aktivoivan opetuksen malliin. Malli pyrkii pois siitä näkemyksestä, että luento-opetus on "opiskelijayleisölle" annettavaa kuivaa esitelmöintiä. Sen sijaan tarkoitus on tarjota opiskelijoita innostava syvällinen oppimiskokemus. Siinä opettajan rooli on selvittää opiskelijoiden aiempia tietoja ja heidän sisäisiä mallejaan keskustelemalla sekä harjoitusten ja tehtävien avulla, tukea heidän oppimisprosessejaan siten, että mahdolliset virhekäsitykset ja ongelmat tulevat esille jo opetuksen aikana (ei vasta tentissä) ja antaa palautetta koko oppimisprosessin ajan (Nevgi ym. 2009, 237-252.) Näissä prosesseissa opettajan kyky virittäytyä kehon eleillä ja tarkentuneella läsnäololla on ensisijaisen tärkeää positiivisen oppimisilmapiirin luomiseksi.

Etnomusikologian peruskursseista Johdatus maailman musiikkikulttuureihin -kurssi on viime vuosina ollut vahvan kritiikin kohteena. Koska kurssilla opitaan musiikkikulttuureista ympäri maailmaa, kysymykset siitä, miten kulttuurien erilaisuutta tulisi käsitellä, ovat vääjäämättömiä. Vahvin kritiikki on kuitenkin kohdistunut siihen, kuinka kolonialismin historia edelleen elää kurssin taustalla vaikuttaen eri tavoin sen sisältöön ja opetustapoihin (Figueroa 2020; Thielsch 2020; Ramstedt 2020). Näihin kysymyksiin ei ole yksinkertaisia ratkaisuja, mutta samalla kun kurssin oppimateriaalin omaksuminen on olennaista, perustavanlaatuinen tavoite tulee olla, että musiikin ja tekstien perusteella käyty dialoginen keskustelu harjaannuttaa opiskelijoita demokraattiseen yhteiselämään.

\section{Dialogin kyky 1: Virittäytyminen}

Opettamallani Johdatus maailman musiikkikulttuureihin -kurssilla olen usein ensimmäisellä luennolla jo ennen varsinaisen luennoinnin alkamista valikoinut populaarimusiikin hittikappaleen virittäytyneen ilmapiirin luomiseen ja keskustelun avaamiseen. Populaarimusiikin äänimaailma ja esitystavat ovat tuttuja useimmille opiskelijoille. Siksi niihin on helppo eläytyä ja ottaa kantaa lyhyilläkin kommenteilla puolesta tai vastaan, jolloin kuitenkin eleet, kasvonilmeet ja monivivahteiset äänenpainot edesauttavat yhteisen resonanssin löytymistä (Alhanen 2016: 137-138). 
Opettajan omaan virittäytyneisyyteen kuuluu se, että hänellä on herkistynyt tietoisuus valtasuhteista suhteessa sekä opiskelijoihin että opetettavaan tietoon. Monissa humanistisissa aineissa onkin siirrytty tutkimuksessa omaa positiota tarkastelevaan reflektiiviseen lähestymistapaan. Opettaessani oman position ymmärtämistä opiskelijoille olen käyttänyt reflektiota omista kenttätyökokemuksistani afrikkalaisamerikkalaisen gospel- ja populaarimusiikintutkijana Yhdysvalloissa. Kerron opiskelijoille avoimesti siitä, miten positioni suomalaisena valkoisena naistutkijana on vaikuttanut vuorovaikutustilanteissani kenttätyön aikana afrikkalaisamerikkalaisissa hengellisissä yhteisöissä. Siten omakohtainen kokemukseni toimii keskustelunavauksena valkoisesta etuoikeudesta sekä uskonnontutkimuksessa sisä- ja ulkopuolisuuteen liittyvistä eettisistä kysymyksistä. Käyn samalla läpi länsimaisen tieteellisen tutkimuksen ongelmallista historiaa ja tärkeyttä tiedostaa sen muokkaama etuoikeutettu asemani yliopistotutkijana.

\section{Dialogin kyky 2: Kuvittelu}

Reflektiivisten keskusteluiden aikana opiskelijat pääsevät myös harjoittelemaan kuvittelemisen kykyä ensin minun ja joskus myös toistensa kokemuksien kautta. Kuten itse opin kenttätyökurssin aikana, kuvittelu tarjoaa kosketuspintaa toisten kokemuksille. Siksi pyrin kokemuksistani kertoessani kontekstualisoimaan ne mahdollisimman tarkasti. Monet opiskelijat ehkä jo tuntevat yhdysvaltalaista yhteiskuntaa oman elämänsä myötä ja he saattavat kuunnella afrikkalaisamerikkalaisia musiikkityylejä, joista kuitenkin musiikin ja elokuvien välityksellä on levinnyt toisinaan ongelmallisia representaatioita. Näen kuitenkin dialogisen keskustelun hengessä tärkeänä korostaa omakohtaista kokemustani paikallishistorian ja kentällä syntyneiden ihmissuhteiden kautta. Siten kommunikoin opiskelijoille kenttäkokemuksien minulle tuottamia merkityksiä ja saatan esimerkiksi kertoa heille, kuinka opin kuuntelemaan rap-artisti Lupe Fiascon musiikkia Quba-instituutin oppilaiden opastamana. Parhaimmillaan omista kokemuksista kertominen johtaa aktiiviseen ajatustenvaihtoon. Yhteisen pohdinnan ja kokemuksien vertailemisen kautta me kaikki saamme monipuolisemman otteen tutkijan oman position tiedostamisessa huomioon otettavista kontekstuaalisista ja omaan identiteettiin liittyvistä tekijöistä.

Yliopistolla toteutetulla kurssilla, kuten Johdatus maailman musiikkikulttuureihin -kurssilla, kuvittelun kyky on hyvin käyttökelpoinen työväline. Jos kurssilla on esimerkiksi vapaavalintainen loppuprojekti, opiskelijat voivat kuvitella vaihtoehtoisia aiheita ja niiden tutkimiseen tarvittavia erilaisia aineistoja. Samoin kuin aiemmin kuvaamallani kenttätyön kurssilla, kuvittelu yliopiston sisäisellä kurssilla auttaa opiskelijoita laajentamaan näkemystä käytössään olevista menetelmistä ja aineistoista. He voivat lisäksi tutustua kurssiaineistosta erilaisiin musiikkikulttuureihin ja eläytyä 
niiden äänimaailmaan luomalla mielikuvia, jotka auttavat muodostamaan suhteita niiden erilaisuuksien ja yhtäläisyyksien välillä. Siten heidän avarakuuloisuutensa kehittyy monin tavoin.

Kuvittelun kyky auttaa myös laajentamaan opiskelijoiden ymmärrystä relativismin periaatteista varsinkin kuunteluharjoitteiden kautta. Kuuntelemisen, keskustelun ja niihin yhdistetyn kuvittelemisen kautta he voivat toisin sanoen saada paremman otteen musiikillisten käytäntöjen erilaisista merkityksistä eri yhteisöissä. Käsiteltäessä musiikkikulttuureja läheltä tai kaukaa opiskelijat tulevat todennäköisesti usein kohtaamaan toiseutta musiikillisissa käytännöissä, oli sitten kyseessä yhteiskuntaluokka, etnisyys, sukupuoli, seksuaalisuus, uskonto tai jokin muu yksilöllisyyttä ja yhteisöllisyyttä määrittävä tekijä. Erityisesti silloin tarkkakorvainen musiikin kuunteleminen antaa oivan lähtöpaikan tarkastelulle. Kaj Ahlsved (2018: 126) tarjoaa kuunteluharjoitteet virikkeiksi keskustelulle, joka "kehittää äänellistä herkkyyttä ja toimii erinomaisena vastalääkkeenä opiskelijoiden tyypilliselle ja hedelmättömälle tavalle asettaa eri musiikkikulttuureja arvojärjestykseen". Omilla kursseillani opiskelijat ovat myös kertoneet musiikin kautta oppineensa ymmärtämään, kuinka musiikkikulttuurien sisäiset arvot eroavat toisistaan ja kuinka musiikkityylit muuttuvat ihmisten ja musiikin liikkuvuuden myötä. Kuuntelemalla esimerkiksi kuubalaista rumba-musiikkia ja oppimalla sen historiasta diasporan käsitteen avulla he ovat saaneet uutta ymmärrystä kolonialismin historian äänellisistä ulottuvuuksista, jotka edelleen kuuluvat musiikissa.

Kuunteluharjoitteiden ohella esimerkiksi kirjallisuuteen perehtyminen ja siihen perustuva keskustelu siirtyvät yleiseltä tasolta omakohtaiseen näkemykseen opiskelijoille asetettujen kysymyksien tuella. Olen käyttänyt Acquahin ja Comminsin (2016: 507) kahta erinomaista esimerkkikysymystä musiikkiin sovellettuna: Mitkä kaksi tärkeää asiaa olet oppinut käsiteltävästä musiikista ja sen merkityksistä yhteisön jäsenille? Miten oppimasi asiat yhdistyvät omiin aiempiin tietoihisi tai kokemuksiisi musiikin parissa? Näin opiskelijat pystyvät harjoittelemaan dialogin kykyihin lukeutuvaa kuvittelutaitoa oppiessaan ihmisten ja yhteisöjen erilaisista suhteista musiikkiin sekä siitä, miten ihmiset käyttävät musiikkia rakentaessaan suhteita toisiinsa.

\section{Dialogin kyky 3: Harkinta}

Olen opetustyössäni huomannut, että kurssin edetessä keskustelun vetäjänä opettajan on kyettävä käyttämään dialogin kyvyistä harkintaa hyvin hienovaraisesti, todellisen osallistavuuden muodostumiseksi. Quba-instituutissa jouduin valintojen eteen keskustellessamme laulun sanoista, sillä tiettyjen laulujen käsitteleminen tai käsittelemättä jättäminen vaikutti siihen, kenen ehdoilla työskentelymme eteni. 
Samoin opetustyön sanavalinnat ja opetusaineistojen sanasto vaikuttaa osallistumisen demokraattiseen toteutumiseen (Koskela \& Leppänen 2020). Opetuksen sisältämä sanasto käytännössä määrittää, ketkä läsnäolijoista tai käsiteltävistä aiheista otetaan mukaan tai suljetaan pois. Silloin sanavalinnat saattavat vaikuttaa yksilöiden tunteeseen opetusyhteisöön kuulumisesta tai siitä poissulkemisesta, kuten käytettäessä pronomineja ("minä", "me" tai "he"), jotka rajaavat keskusteltavan aiheen kokemuksellista piiriä (Söderlundh 2018:325). Tähän aiheeseen liittyen Helsingin yliopistolla hiljattain perustettu Students of Color -organisaatio on tuonut esille luokkahuoneeseen liittyviä käytäntöjä, joihin opettajien on kiinnitettävä huomiota. Students of Color -organisaation jäsenet Aracelis Correa, Janina Ojala ja Jenny Kasongo ovat nostaneet esille oletuksen valkoisesta normatiivisuudesta opetuksessa ja mainitsevat, että joissain oppimateriaaleissa olevat rasistista väkivaltaa käsittelevät aineistot voivat olla loukkaavia. Samoin oletus opetettavissa aineistoissa käsiteltävien ihmisten olemisesta "jossain muualla" ei ole hyvä lähtökohta opetukseen (Kopra 2020; Toivonen 2020).

Pennsylvanian yliopistolla olin opettanut kursseja englannin kielellä, ja opetustyössäni olin oppinut hallitsemaan tieteellistä sanastoa, jonka turvin pystyin ilmaisemaan vaikeitakin asioita. Kun aloitin opettamisen Helsingin yliopistolla suomeksi, jouduin harkitsemaan sanavalintojani täysin uudella tavalla suomen kieliopin, historian ja kulttuurin risteyksessä. Tiedostin, että tiettyihin sanoihin liittyi erilaisia merkityksiä eurooppalaisessa kontekstissa. Siksi pohdin jo luentoa valmistellessani, mitä termejä tulen käyttämään luennon aikana ja miten opastan opiskelijoita sopivan sanaston käyttämiseen keskustelussa. Esimerkiksi luennoidessani jazzmusiikin historiasta käytän termiä "afrikkalaisamerikkalainen" vanhahkon, mutta edelleen käytössä olevan sanan "afroamerikkalainen" sijaan. Anna Rastas on kirjoittanut (2018) termien historiallisesta taakasta Skandinaviassa. Hän argumentoi, että on tärkeää kehittää sanastoa, joka edesauttaa rodullistamiseen ja etnisyyteen liittyvien ongelmien tutkimista. ${ }^{3}$ Olen samaa mieltä Rastaan kanssa, ja ehdotankin, että etnomusikologian kurssien opettajat voivat keskeisesti osallistua tämän sanaston mietintään ja kehittämiseen valmistellessaan ja toteuttaessaan opetusta.

Luennolla saattaa myös joku osallistuja ilmaista avoimesti rasistisen mielipiteen. Professori Heidi Safia Mirza sanoo, että silloin opettajan kannattaa ohjata keskustelu rasismin kritiikkiin. Hän myös tunnustaa, että se ei ole helppoa, ja ohjeistaa tarjoamaan opettajille tukea ja työkaluja rasismin vastaiseen toimintaan luokkahuoneessa (Smeds 2016). Tämä on myös keskeistä opettajien koulutuksessa, koska opettajat

3 Ks. myös kuinka "rotu" sosiaalisena kategoriana ja rodullistetut suhteet kannattaisi ottaa huomioon suomalaisessa tieteellisessä keskustelussa: Rastas \& Poelman 2021. 
opettavat koko ajan monikulttuurisempia luokkia (Acquah \& Commins 2016). Nykyhetkessä on tarve opetukselle, jonka kautta opiskelijat voivat harjoitella dialogisen keskustelun harkinnan kykyä rakentavasti ja turvallisesti. On opettajien vastuulla luoda uudenlaisia kursseja, joilla opetellaan puhumaan niistä vaikeistakin asioista, joita opiskelijat kohtaavat jokapäiväisessä elämässään. Etnomusikologi Stephanie Shonekan (2018: 114) nostaa esimerkeiksi tämänkaltaisista kursseista Marcia Chatelainin kurssin \#Ferguson ja Frank Leon Robertsin kurssin Black Lives Matter.

\section{Dialogin kyky 4: Leikki}

Kuten Quba-instituutin kokemus minulle opetti, leikki voi toimia tieteellisenä työkaluna sekä rikastuttaa tutkimusta ja oppimiskokemusta. Yliopistolla toteutetulla kurssilla dialogin kyvyistä leikkiä voi hyödyntää varsinkin aktivoivissa oppimismenetelmissä. Niistä esimerkkinä kulttuurisen omimisen aiheisiin keskittyvät debattikisat, joita pidetään maailman musiikkikulttuureja käsittelevillä kursseilla. Leikin tapaan olen myös käyttänyt toiminnallisia tehtäviä. Olen esimerkiksi antanut opiskelijoille tehtäväksi kartoittaa Helsingin monipuolista musiikkikulttuuria seuraten Philip Bohlmanin (2016) eurooppalaista musiikkikulttuuria käsittelevän tekstin mallia. Tavallista turistikarttaa apuna käyttäen opiskelijat ovat tehneet kirjallisia ja kuvallisia merkintöjä musiikillisesta elämästä Helsingissä. Karttojen taiteellista ja tieteellistä lopputulosta tärkeämpää on osallistujien luovuuden ohjaama keskustelu ja kokeileminen erilaisilla asetelmilla. Mitkä kohteet jo näkyvät kartalla ja miksi? Mitä muuta musiikillista toimintaa tulisi merkitä, esimerkiksi katusoittajat? Entä musiikin opiskeluun liittyvät paikat? Töiden pohjalta on mahdollista edetä myös keskustelemaan muista aiheista, kuten globalisaation ja kolonialismin kytkeytymisestä musiikkiin sekä musiikin kaupallistamiseen liittyvistä prosesseista.

Kaiken kaikkiaan leikin opetteleminen on myös tärkeää tulevaisuuden tutkijoiden kouluttamisessa. Kuten Sanna Ryynänen ja Anni Rannikko toimittamassaan tuoreessa teoksessa ehdottavat, nykyajan tieteessä ollaan siirtymässä yhä enemmän avarakatseiseen tiedontuotantoon, johon olennaisesti liittyy luovien, osallistuvien ja toiminnallisten tutkimusmenetelmien hyödyntäminen. Heidän mukaansa avarakatseinen ote tiedon tuottamiseen käsittää sekä taidetta ja tiedettä yhdistelevät menetelmät että monet erilaiset "luovaa heittäytymistä" vaativat menetelmät (Ryynänen \& Rannikko 2021: 17). Yllä mainitun musiikillisen kartan tapaan Johanna Hohenthal kuvaa samaisessa teoksessa osallistavan kartoituksen mahdollisuuksia ympäristösuhteiden tutkimuksessa. Hänen mukaansa "yhteisön edustajien tai yksilöiden piirtämät kartat, joissa he kuvaavat lähiympäristöään ja merkitsevät siihen tutkimusaiheen näkökulmasta tärkeiksi kokemiaan yksityiskohtia, voivat olla tärkeä osa tiedon tuottamisen prosessia” (Hohenthal 2021: 154). Tämä luova suuntaus tieteen tuottamisessa 
kannattaa huomioida opetuksessa. Tulevaisuuden etnomusikologeille ja muille musiikista kiinnostuneille opiskelijoille on annettava valmiuksia käyttää luovia ja kokeilevia menetelmiä tiedon hankinnassa.

\section{Dialogin kyky 5: Usko}

Opiskelijat kohtaavat erilaisuutta lukemattomin eri tavoin. Omien ja muiden kokemuksien käsitteleminen vaatii tietoista pyrkimistä pois kaavamaisista ajattelumalleista ja hienovaraista avoimuutta ajatustenvaihdolle. Etnomusikologian kursseilla voi harjoitella kaikkia edellä mainittuja dialogin kykyjä, mutta parhaimmillaan ne antavat tilaisuuden vahvistaa uskoa demokraattisen yhteiskunnan ideaaleihin. Opetuksen aikana käsitellään kurssimateriaaleja keskustelun kautta, mutta tieto välittyy myös hymyissä ja muissa kasvojen ilmeissä sekä kehon eleissä. Parhaimmillaan nämä pienetkin eleet vahvistavat, että kyky uskoa demokraattiseen yhteiselämään on opetuksen sisällöistä ehkä kaikkein tärkein.

\section{Lopuksi}

Nykyhetkessä on erityisen tärkeää nostaa esille etnomusikologian kuten muidenkin humanististen aineiden opetuksen yhteiskunnallinen arvo, koska humanististen alojen koulutuspoliittinen tilanne on heikentynyt merkittävästi viime vuosikymmenien saatossa (Seye 2020; Mäkelä \& Haapoja-Mäkelä 2019). Viime aikoina tämä tilanne on tullut esille kiivaana julkisena keskusteluna, jonka kirvoitti Helsingin yliopiston taiteiden tutkimuksen opiskelijoiden kannanotto vähentyneeseen opetukseen (ks. Hiidenmaa \& Erkkilä-Hill 2021; Klinge ym. 2021; Kärjä 2021; Leisiö \& Gronow 2021; Moisala 2021; Sirén 2021a, 2021b; Tiainen 2021). Kyseessä ei ole vain yhden tieteellisen yhteisön kriisi, vaan laajempi kamppailu siitä, mikä on yhteiskunnallisesti merkityksellisestä tiedettä ja sen opetusta. Kaiken kaikkiaan yliopistoissa vallitsevat määrälliset kriteerit, vähenevät resurssit ja markkinahenkisyys ovat aiheuttaneet paineita tavoitteiden priorisointiin. Koulutusohjelmien on panostettava joko "tehokkuuteen" (mitattuna opintopisteillä ja valmistuneiden opiskelijoiden määrällä) tai yleisesti tunnustettujen taitojen oppimiseen tai transformatiivisen oppimiskokemuksen tuottamiseen (Harvey \& Green 1993, sit. Biggs 2001: 221-222). Näistä vaihtoehdoista transformatiivisen oppimiskokemuksen "tuottavuutta" on vaikea mitata, joten poliittisessa päätöksenteossa sitä on hankala puolustaa. Tämä on oletettavasti yksi syy sille, että sivistyksen lisäämiseen tähtäävät humanistiset aineet, kuten etnomusikologia, ovat olleet säästötoimenpiteiden kohteina.

Tästä kaikesta huolimatta etnomusikologia on elinvoimainen tieteenala, joka on hyvin asemoitunut toteuttamaan yliopistojen yhteiskunnallista tehtävää. Etnomusikologian 
kurssit mahdollistavat yhteiskunnallisesti vaikuttavan opetuksen, jollainen Kaj Ahlsvedin mukaan "sisältää vuorovaikutuksellista keskustelua, palautteen saamista ja toisilta oppimista" (Ahlsved 2018: 118). Kuten Ahlsved myös toteaa (2018: 118-124), tutkija-opettaja, jonka pedagogista ajattelua ohjaa aktivistinen lähestymistapa, tukee opiskelijan oman ajattelun kehittämistä ja rohkaisee häntä suhtautumaan kriittisesti vallitsevien aatteiden ja käsitteiden järjestelmiin. Tämän kaltaisessa opetustyössä opettaja nostaa epäoikeudenmukaisuuksia puheenaiheiksi rohkaisten vuorovaikutuksellista keskustelua, on avoin uusille ajatuksille ja voi opetuksessaan myös hyödyntää kyseenalaistamista ja kokeellisuutta. Ahlsved nostaa esille myös kuuntelun taidon tärkeyden soivan ympäristön ja sen kuttuuristen merkitysten ymmärtämiselle (2018: 124-126).

Ehdotan, että kuuntelun taito on erityisen tärkeä myös dialogin kykyjen kehittymiselle. Samalla kun kuuntelun taidon kehittyminen antaa valmiuksia ympäristön moninaisuuden ymmärtämiseen, se auttaa ymmärtämään musiikillisen kommunikaation monipuolisuutta ja harjaannuttaa avarakuuloisuuteen erilaisten ihmisten välisissä vuorovaikutustilanteissa. Esitän, että Alhasen tarjoamaa dialogin kykyjen mallia voisi soveltaa ja laajentaa musiikkiaineiden opetuksessa keskittymällä erityisesti kuuntelun taitojen harjaannuttamiseen. Siihen musiikkitieteelliset oppimateriaalit, pedagogiset lähestymistavat ja opiskelun äänelliseen ilmaisuun keskittyvät painoalueet sopivat erityisen hyvin. Käytännössä esimerkiksi Johdatus maailman musiikkikulttuurit -kurssia suunnitellessa voisi kirjata dialogin kykyjen harjoittamisen oppimistavoitteisiin ja kannustaa opiskelijoita reflektoimaan erityisesti kuuntelun kykyjen harjoittelemista kurssin lopussa kirjoitettavassa reflektiopaperissa. Kaiken kaikkiaan etnomusikologian osallistava opetus voi tarjota oppimisilmapiirin, jossa opiskelijat pääsevät musiikkilähtöisesti ja kuuntelupainotteisesti harjoittelemaan dialogin kykyjä turvallisessa ympäristössä. Siten etnomusikologian osallistava opetus voi toimia tärkeiden kansalaistaitojen kehitysalustana. 


\section{Lähteet}

\section{Tutkimusaineisto}

Öhman, Nina C. (2008) Kenttämuistiinpanot 11.2.2008. Aineisto kirjoittajan hallussa.

University of Pennsylvania and Quba Institute of Arabic and Islamic Studies. 2008. Hip Hop and Us multimedia project. Philadelphia, PA.

\section{Sanomalehdet ja blogit}

Brown, Danielle (2020) "An Open Letter on Racism in Music Studies. Especially Ethnomusicology and Music Education”. Published 12.6.2020. My People Tell Stories. https://www.mypeopletellstories.com/blog/open-letter (luettu 16.4.2021).

Hiidenmaa, Pirjo \& Erkkilä-Hill, Jaana (2021) "Voimia yhdistämällä tuotetaan enemmän ja monipuolisempaa koulutusta". Helsingin Sanomat 10.3.2021. https://www.hs.fi/mielipide/art-2000007849654.html (luettu 14.6.2021).

Klinge, Matti \& Lintu, Hannu \& Meurman, Jukka \& Mälkki, Susanna \& Saariaho, Kaija \& Vartiainen, Juhana (2021) "Musiikkitiede on palautettava sille kuuluvalle kunniapaikalle". Helsingin Sanomat 6.3.2021. https://www.hs.fi/mielipide/art-2000007843378.html (luettu 16.4.2021).

Kopra, Jasmin (2020) "Student association SOCO promotes equality at the University". University of Helsinki News. 30.10.2020. https://www2.helsinki.fi/ en/news/higher-education-science-policy/student-association-socopromotes-equality-at-the-university (luettu 12.4.2021).

Kärjä, Antti-Ville 2021. "Huoli musiikkitieteen ahdingosta on itse aiheutettua". Helsingin Sanomat 24.2.2021. https://www.hs.fi/mielipide/art2000007821149.html (luettu 16.4.2021).

Leisiö, Timo \& Gronow, Pekka (2021) "Virkojen katoaminen johtaa musiikkitieteen kuihtumiseen". Helsingin Sanomat 17.2.2021. https://www.hs.fi/mielipide/art-2000007806346.html (luettu 16.4.2021).

Moisala, Pirkko (2021) "Monipuolista musiikintutkimusta on jatkettava". Helsingin Sanomat 12.3.2021. https://www.hs.fi/mielipide/art-2000007854253.html (luettu 16.4.2021).

Sirén, Vesa (2021a) "Taiteiden tutkimus on pulassa Helsingin yliopistossa Professorikato kuormittaa opettajia, opiskelijat jäävät vaille opetusta: 'Tilanne on raskas"'. Helsingin Sanomat 8.2.2021 https://www.hs.fi/kulttuuri/art-2000007790743.html (luettu 16.4.2021).

Sirén, Vesa (2021b) "Taiteiden tutkimuksen kriisi jatkuu Helsingin yliopistossa: Opiskelijakyselyssä lähes puolet harkitsee pääaineen vaihtamista". Helsingin Sanomat 2.3.2021. https://www.hs.fi/kulttuuri/art-2000007835636.html (luettu 16.4.2021). 
Smeds, Mia (2016) "Racism can be beaten in the classroom". University of Helsinki Newsletter 11.3.2016. https:/www.helsinki.fi/en/news/education/racism-canbe-beaten-in-the-classroom (luettu 16.4.2021).

Tiainen, Milla (2021) "Musiikkitiedettä ei pidä ajaa alas Helsingin yliopistossa". Helsingin Sanomat 14.2.2021. https:/www.hs.fi/mielipide/art2000007801743.html (luettu 16.4.2021).

Toivonen, Hilma (2020) "Luennoilla kuulee rasistista kieltä" - Joukko opiskelijoita kyllästyi yliopiston syrjivään kulttuuriin ja perusti opiskelijajärjestö Students Of Colourin: Syrjinnän kohtaamisen pelko saattaa vaikuttaa jopa opintoalan valintaan. Yle 13.1.2020. https:/yle.fi/uutiset/3-11142191 (luettu 20.4.2021).

\section{Tutkimuskirjallisuus}

Acquah, Emmanuel O. \& Commins, Nancy L. (2013) "Methods that matter in addressing cultural diversity with teacher candidates". Teaching in Higher Education 22:5, 501-518. https://doi.org/10.1080/13562517.2016.127317

Ahlsved, Kaj (2018) "Tutkija mediatoimijana, kansanvalistajana ja musiikkikouluttajana: yhteiskuntavastuun mahdollisuudet ja haasteet". Musiikki muutosvoimana. Aktivistisen musiikintutkimuksen manifesti. Toim. Sini Mononen ja Susanna Välimäki. Helsinki: Tutkimusyhdistys Suoni ry, 107-126.

Alhanen, Kai (2016) Dialogi demokratiassa. Helsinki: Gaudeamus.

Alviso, Ric (2010) "Community Service-Learning in World Music Courses". SEM Newsletter 44: 2, 1, 6-7.

Araujo, Samuel (2009) "Ethnomusicologists researching towns they live in:

Theoretical and methodological queries for a renewed discipline".

Muzikologija 9, 33-50. https://doi.org/10.2298/MUZ0909033A

Averill, Gage (2010) "Weapons of Mass Instruction: Engaged Ethnomusicology, Service Learning, and Global Citizenship". SEM Newsletter 44: 2, 1, 8, 12.

Averill, Gage (2003) "Ethnomusicologists as Public Intellectuals: Engaged Ethnomusicology in the University". Folklore Forum 34:1/2, 49-59.

Barz, Gregory \& Cooley, Timothy J. (toim.) (2008) Shadows in the Field. New Perspectives for Fieldwork in Ethnomusicology (2nd ed). New York: Oxford University Press.

Biggs, John (2001) "The reflective institution: Assuring and enhancing the quality of teaching and learning". Higher Education 41, 221-238. https://doi.org/10.1023/A:1004181331049

Bohlman, Philip V. (2016) "The Musical Culture of Europe". Excursions in World Music. 7th ed. Toim. Bruno Nettl \& Timothy Rommen. New York: Routledge, 302-337. 
Campbell, Elizabeth \& Lassiter, Luke Eric (2014) Doing Ethnography Today:

Theories, Methods, Exercises. Hoboken: Wiley Blackwell.

Diamond, Beverley \& Castelo-Branco, Salwa El-Shawan (toim.) (2021a)

Transforming Ethnomusicology. Methodologies, Institutional Structures \& Policies,

Vol I. New York: Oxford University Press.

https://doi.org/10.1093/oso/9780197517604.001.0001

Diamond, Beverley \& Castelo-Branco, Salwa El-Shawan (toim.) (2021b)

Transforming Ethnomusicology. Political, Social, and Ecological Issues, Vol 2.

New York: Oxford University Press.

https://doi.org/10.1093/oso/9780197517550.001.0001

Donner, Philip (1984) "Nipe nikupe!”. Musiikin suunta 3, 3.

Figueroa, Michael A. (2020) "Decolonizing 'Intro to World Music?". Fournal of Music History Pedagogy 10:1, 39-57.

Furco, Andrew \& Norvell, Katrina (2019) "What Is Service Learning? Making

Sense of The Pedagogy and Practice". Embedding Service Learning in European Higher Education: Developing a Culture of Civic Engagement. Toim. Pilar Aramburuzabala, Lorraine McIlrath \& Héctor Opazo. Boca Raton:

CRC Press Taylor \& Francis Group, 13-35.

https://doi.org/10.4324/9781315109053-2

Gould, Jeremy (2016) "Refleksiivisyyden poluillla, epistemologisesti radikaalin yhteiskuntatieteen puolustus". Tutkija peilin edessä. Refleksiivisyys ja etnografinen tieto. Toim. Jeremy Gould \& Katja Uusihakala. Helsinki: Gaudeamus, 9-37.

Gould, Jeremy \& Uusihakala, Katja (toim.) (2016) Tutkija peilin edessä. Refleksiivisyys ja etnografinen tieto. Helsinki: Gaudeamus.

Gubner, Jennie (2018) "The Music and Memory Project: Understanding Music and Dementia through Applied Ethnomusicology and Experiential Filmmaking". Yearbook for Traditional Music 50, 15-39. https://doi.org/10.5921/yeartradmusi.50.2018.0015

Harrison, Klisala \& Mackinlay, Elizabeth \& Pettan, Svanibor (toim.) (2010) Applied Ethnomusicology: Historical and Contemporary Approaches. Newcastle upon Tyne: Cambridge Scholarly Publishing.

Harvey, Lee \& Green, Diana (1993) "Defining Quality". Assessment and Evaluation in Higher Education 18, 8-35. https://doi.org/10.1080/0260293930180102

Hess, Juliet (2019) Music Education for Social Change: Constructing an Activist Music Education. Abingdon: Routledge. https://doi.org/10.4324/9780429452000

Hohenthal, Johanna (2021) "Osallistuva kartoitus ympäristösuhteiden tutkimuksessa". Tutkiva mielikuvitus, luovat, osallistuvat ja toiminnalliset tutkimusenetelmät yhteiskuntatieteissä. Toim. Sanna Ryynänen \& Anni Rannikko. Helsinki: Gaudeamus, 154-177. 
Järviluoma, Helmi (2005) "Ajan hengen lyhyt historia. Suomen Etnomusikologinen Seura 1970-80-lukujen vaihteessa". Musiikin suunta 27:2, 59-66.

Järviluoma, Helmi (2008) "Etnomusikologi kulttuurintutkijana - pakkoavioliitto vai aito romanssi?" Kulttuurintutkimus 25:2, 11-24.

Järviluoma, Helmi \& Leppänen, Taru (2004) "'Jos metsään haluat mennä nyt' Osallistava musiikkietnografia ja eksymisen metodologia". Kulttuurintutkimus $21: 3,35-41$.

Järviluoma, Helmi \& Leppänen, Taru (2012) "Becoming Audible! Asylum seekers, participatory action research and cultural encounters". Situating Popular Musics, IASPM 16th International Conference Proceedings. Toim. Ed Montano \& Carlo Nardi, IASPM - International Association for the Study of Popular Music, 297-306. https://doi.org/10.5429/2225-0301.2011.40

Koskela, Minja \& Leppänen, Taru (2020) "How democratic is popular music in Finnish schools? Exploring popular music education through intersectionality". Fournal of Popular Music Education 4:3, 295-309. https://doi.org/10.1386/jpme_00031_1

Kurkela, Vesa (2005) "Etnomusikologian sukupolvet". Musiikin suunta 27:2, $47-58$.

Mezirow, Jack (1997) "Transformative learning: Theory to Practice". New Directions for Adult \& Continuing Education 74, 5-12.

https://doi.org/10.1002/ace.7401

Mezirow, Jack \& Lehto, Leevi \& Ahteenmäki-Pelkonen, Leena (1996) Uudistava oppiminen: kriittinen reflektio aikuiskoulutuksessa (2.painos). Helsingin yliopiston Lahden tutkimus- ja koulutuskeskus.

Mikkeli, Heikki \& Pakkasvirta, Jussi (2007) Tieteiden välissä? fohdatus monitieteisyyteen, tieteidenvälisyyteen ja poikkitieteisyyteen. Helsinki: WSOY Oppimateriaalit Oy.

Moisala, Pirkko (1994) "The Wide Field of Finnish Ethnomusicology" Ethnomusicology 38:3, 417-422. https://doi.org/10.2307/852108

Moisala, Pirkko \& Seye, Elina (2013) "Johdanto". Musiikki kulttuurina. Toim. Pirkko Moisala \& Elina Seye. Helsinki: Suomen Etnomusikologinen Seura, $5-7$.

Mononen, Sini \& Välimäki, Susanna (toim.) (2018) Musiikki muutosvoimana. Aktivistisen musiikintutkimuksen manifesti. Helsinki: Tutkimusyhdistys Suoni ry.

Muller, Carol Ann \& Öhman, Nina C. (2021) "On Not Knowing: Academically Based Community Service, Faith Based Organizations, and the Transformation of Ethnomusicological Praxis". Transforming Ethnomusicology. Methodologies, Institutional Structures E Policies, Vol. I. Toim. Beverley Diamond \& El-Shawan Castelo-Branco. New York: Oxford University Press, 151-168. https://doi.org/10.1093/oso/9780197517604.003.0010 
Mäkelä, Janne \& Haapoja-Mäkelä, Heidi (2019) "Etnomusikologian hyvät ja huonot uutiset". Etnomusikologian vuosikirja Vol. 31, 6-8. https://doi.org/10.23985/evk.86178

Nevgi, Anne \& Lindblom-Ylänne, Sari (2009) "Oppimisen teoriat". Yliopistoopettajan käsikirja. Toim. Sari Lindblom-Ylänne \& Anne Nevgi. Helsinki: WSOYpro, 194-236. https://doi.org/10.31885/9789515150325

Nevgi, Anne \& Lonka, Kirsti \& Lindblom-Ylänne, Sari (2009) "Aktivoiva luentoopetus" Yliopisto-opettajan käsikirja. Toim. Sari Lindblom-Ylänne \& Anne Nevgi. Helsinki:WSOYpro, 237-253. https://doi.org/10.31885/9789515150325

Pettan, Svanibor \& Titon, Jeff Todd (2015) The Oxford Handbook of Applied Ethnomusicology. New York: Oxford University Press. https://doi.org/10.1093/oxfordhb/9780199351701.001.0001

Piekkari, Jouni (2002) Paikalliset äänet osallistavassa kulttuurityössä: etnomusikologinen ja osallistava näkökulma ammatilliseen kasvuuni. Pro gradu -tutkielma. Tampere: Tampereen yliopisto.

Ramstedt, Kim (2020) "Valkoisuus Suomen musiikintutkimuksessa". Esitelmä Musiikintutkijoiden virtuaalifoorumissa. Musiikin suunta 2.

Rannikko, Anni \& Rannikko Pertti (2021) "Autoetnografia ja vaikenemisen kulttuuri". Tutkiva mielikuvitus. Luovat osallistuvat ja toiminnalliset tutkimusmenetelmät yhteiskuntatieteissä. Toim. Sanna Ryynänen \& Anni Rannikko. Helsinki: Gaudeamus, 57-81.

Rastas, Anna (2018) "The Emergence of Race as a Social Category in Northern Europe" Relating Worlds of Racism, Dehumanization, Belonging and the Normativity of Whiteness. Toim. Philomena Essed \& Karen Farquharson \& Elisa Joy White \& Kathryn Pilay. London: Palgrave Macmillan, 357-381. https://doi.org/10.1007/978-3-319-78990-3_14

Rastas, Anna \& Poelman, Sanna (2021) "Suomalaisen sosiologian värisokeapiste". Sosiologia 1, 3-20.

Rice, Timothy (2008) "Toward a Mediation of Field Methods and Field Experience in Ethnomusicology". Shadows in the Field, New Perspectives for Fieldwork in Ethnomusicology, 2nd ed. Toim. Gregory Barz \& Timothy J. Cooley. New York: Oxford University Press, 42-61.

Rommen, Timothy (2016) "Introduction: Studying Musics of the World's Cultures". Excursions in World Music. 7th ed. Toim. Bruno Nettl \& Timothy Rommen. New York: Routledge, 1-17.

Ruusuvuori, Johanna \& Tiittula, Liisa (2017) "Tutkimushaastattelu ja vuorovaikutus". Tutkimushaastattelun käsikirja. Toim. Matti Hyvärinen, Pirjo Nikander \& Johanna Ruusuvuori. Tampere: Vastapaino, 46-83.

Ryynänen, Sanna \& Rannikko, Anni 2021. "Johdanto". Tutkiva mielikuvitus. Luovat osallistavat ja toiminnalliset tutkimusmenetelmät yhteiskuntatieteissä. Helsinki: Gaudeamus. 
Seye, Elina (2020) "Etnomusikologian olemassaolosta". Musiikin suunta http://musiikinsuunta.fi/2020/ajankohtaista/etnomusikologianolemassaolosta/ (luettu 1.12.2021).

Seye, Elina \& Tiainen, Milla (2021) "Sisäpiirejä ja sukupuolijakoja? Musiikintutkimuksen syrjintäkysely herätti keskustelua". Musiikin suunta http://musiikinsuunta.fi/2021/05/08/sisapiireja-ja-sukupuolijakojamusiikintutkimuksen-syrjintakysely-heratti-keskustelua/ (luettu 1.12.2021).

Shonekan, Stephanie (2018) "Conclusion: Race, Place, and Pedagogy in the Black Lives Matter Era". Black Lives Matter and Music: Protest, Intervention, Reflection. Toim. Fernando Orejuela \& Stephanie Shonekan. Bloomington: Indiana University Press, 111-117. https://doi.org/10.2307/j.ctv75d8jt. 11

Summit, Jeffrey A. (2015) "Advocacy and the Ethnomusicologist: Assessing Capacity, Developing Initiatives, Setting Limits, and Making Sustainable Contributions". The Oxford Handbook of Applied Ethnomusicology. Toim. Svanibor Pettan \& Jeff Todd Titon. New York: Oxford University Press, 199-228. https://doi.org/10.1093/oxfordhb/9780199351701.013.9

Söderlundh, Hedda (2018) "Internationalization in the Higher Education Classroom: Local Policy Goals Put Into Practice". Fournal of Studies in International Education 22:4, 317-333. https://doi.org/10.1177/1028315318773635

Thielsch, Angelika (2020) "Listening out and dealing with otherness. A postcolonial approach to higher education teaching". Arts and Humanities in Higher Education 19:3, 227-243. https://doi.org/10.1177/1474022219832459 Titon, Jeff Todd (2008) "Knowing Fieldwork". Shadows in the Field, New Perspectives for Fieldwork in Ethnomusicology, 2nd ed. Toim. Gregory Barz \& Timothy J. Cooley. New York: Oxford University Press, 25-41.

Usner, Eric Martin (2010) "United States Ethnomusicology and the Engaged University". Applied Ethnomusicology: Historical and Contemporary Approaches. Toim. Klisala Harrison, Elizabeth Mackinlay, and Svanibor Pettan. Newcastle upon Tyne: Cambridge Scholars, 76-95.

Yliopistolaki 24.7.2009/558.

Åberg, Kai Viljami (2020) Romanihäät (ven. свадьба Roma) - Musiikki ja tanssi

Suomen ja Venäjän Karjalan Romanien parissa. Esitelmä Musiikintutkijoiden virtuaalifoorumissa. Musiikin suunta 2.

Öhman, Nina C. (2020) Palveluoppiminen musiikkitieteessä. Musiikki 50:1-2, 204-212. 